\title{
Application of Internet for Service Delivery in Selected Special Libraries in Kaduna Metropolis
}

\author{
Ikegwuiro, Patience Uloaku (MLS) \\ Librarian1, National Water Resources Institute, \\ Mando Road, Kaduna, Nigeria
}

doi: 10.19044/esj.2017.v13n7p411 URL:http://dx.doi.org/10.19044/esj.2017.v13n7p411

\begin{abstract}
The study investigated the Application of Internet for service delivery in some selected special libraries in Kaduna state. The objectives of the study were to ascertain the kind of Internet services used in the special libraries; to ascertain the library services where internet is applied; to find out the extent of internet application in library services; to ascertain the level of satisfaction of the staff with the application of the Internet and to determine the factors that hinder the effective application of Internet in the libraries. Survey method of research was adopted. The population of the study was made up of 38 library staff from the four (4) selected special libraries. Descriptive statistical tools such as simple percentages and tables were used to analyze the data. The study revealed that the application of Internet to library services is not significantly high. The study also found out that the librarians derive satisfaction in the application of Internet in their library services because it helps for effective services delivery, though some factors were discovered to be a hindrance for effective application of the Internet in the special libraries which include: low bandwidth; poor funding; erratic power supply, technology obsolescence and high cost of connectivity and maintenance. The study recommends that Internet services should be adequately used by the special libraries in Kaduna metropolis in carrying out the housekeeping operations and services of the library; libraries administrations in Kaduna metropolis should make sure that there is steady power supply in the libraries for effective use of the Internet services for service delivery; The special libraries should make sure that Internet facilities are serviced regularly; and training of staff on for effective use of the Internet. The study concludes that special libraries in Kaduna metropolis are still on the verge of meeting up with the global perspective of ICT compliance. This notwithstanding, the Internet services are available in such a way that libraries can apply them to library service to enhance the quality of their service delivery.
\end{abstract}


Keywords: Application, Library Services, Internet, Special Library, Information.

\section{Introduction}

Computer and communication technologies have modernized the whole world of information and have penetrated in areas beyond libraries transforming nearly every aspect within society. Application of Internet and other network resources is changing the traditional library functions. In a special library Internet is applied to provide easy access to current information and convenient information exchange. Internet is an abbreviation for International Network. It is not a single Network but a collection of computers worldwide through a system of connection that use the standard Internet Protocol Suite (TCP/IP) to serve billions of users worldwide. According to Adesanya (2002), Internet is a collection of computer networks that connects million of computers around the world. It is known as the "Information Super Highway". It is increasingly becoming the solution to many information problems, information exchange, gathering and marketing. According to Gbaje (2002), the Internet is the network of networks linking millions of computer together. It has the ability and capability to provide adequate, current, and timely services to information seekers wherever they are. The Internet helps the user to perform a range of positive practical applications such as ability to conduct research, perform business transactions and access international libraries.

Internet services are the various services that are available in the Internet. In order to connect to the Internet, you need to use an Internet service. Internet services provide a way for data to be transferred from Internet servers to your computer. Muzakkari (2002) stated that Internet services are the resources available in the net. These electronic resources include: e-mail, chat groups, file Transfer Protocol, gopher, telnet, chat and instant messaging, discussion group, and World Wide Web. Internet services are a major source by which library and information centres can effectively provide information services to its increasing population of users in this rapidly growing environment of information explosion and availability. In the developed countries, and even some developing countries like Nigeria, Internet services are being used extensively for services delivery, including special libraries.

A Special library is one of the types of libraries that require the application of ICTs. A special library is a library maintained by corporation, association, government agency or any other group. It can also be defined as a specialized or departmental collection within a library for the organization and dissemination of information and primarily offering services to a 
specialized clientele through the use of varied media and methods (Madu and Adeniran, 2005). Imeremba (2004) opined that a special library exists to serve a specialized body of users within a definite subject field. Special libraries do not exist for their own sake. Rather, it is established as part of a larger organization in order to obtain and exploit specialized information for the private use of the organization that provides its financial support. A typical special library resources/collections will include periodicals, book/monographs, reference materials, abstracts/indexes, pamphlets, chippings, patents, reports, maps, trade literature, audio visual, multi-media resources and other ICT components. Their services will include Selective Dissemination of Information (SDI), current literature search, indexing and abstracting, publishing, translating, bibliographic services, document supply, exchange of information etc. (Dirisu, 2002)

Special libraries exist mainly to cater for the information needs of specialized clientele, and to ensure that library services are given within the framework of users needs and in keeping with the aims and objective of that library. For effective rendering of services by any special library application of Internet resources is central.

Kaduna state occupies part of the central position of the Northern part of Nigeria (with Kaduna as its capital). It shares common borders with Zamfara, Katsina, Niger, Kano, Bauchi and Plateau states. To the SouthWest, the state shares a border the Federal Capital Territory, Abuja. The state occupies an area of approximately 48,473.2 square kilometers and has a population of more than 6 million (2006 census). The entire land structure consists of an undulating plateau with major rivers in the state including river Kaduna, River Wonderful in Kafanchan, River Kagon, River Gurara and Galma. The state has 23 Local Government Areas.

Kaduna is one of the centres of education in Nigeria. A number of notable educational institutions in the country are located in the state. They are Ahmadu Bello University, Zaria, Kaduna Polytechnic, Kaduna, School of Health Technology, the Federal Fishery Training Institute, Kaduna, National Water Resources Institute, Mando, National Teachers Institute, Nigerian Institute for Trypanosomiasis Research, Surami Road, Police College, Kaduna, Nigerian Defence Academy, National Board for Technical Education, Kaduna; National Research Institute for Chemical Technology (NARICT), Zaria etc.

The application of Internet in special libraries has tremendously changed the management of resources or housekeeping operations as well as the way services are delivered. The Internet holds great potentials in libraries; its services are largely used in housekeeping operations, like acquisition, cataloguing, circulation control, serials management etc. The Internet can be used to deliver the information needs of the users in special 
libraries. Oketunji (2001) stated that Internet gives access to a vast wealth of knowledge much of which may not be possible to access without the Internet services. The Internet provides access to a tremendous variety of information, allows access to remote libraries and creates an environment where users can have innovative, co-operative learning experience.

This study investigated the application of Internet for service delivery in special libraries which includes: Nigerian Institute for Trypanosomiasis Research, Surami Road, National Water Resources Institute, Mando, Court of Appeal, Kawo, Federal High Court, Kawo, all in Kaduna State. The type of Internet resources available and services rendered to the users and the problems of application of Internet in the libraries will be studied with a view to providing solution.

\section{Statement of the Problem}

The application of Internet in library services increases efficiency and effectiveness and also ensures the delivery of timely, accurate, precise and relevant information to patrons. It also places librarians in a position to face the $21^{\text {st }}$ century challenges of global information society.

Internet has increased not only the quality of traditional library services but also has made it possible for libraries to pioneer in new services in a constantly changing environment. It plays a significant role in area of effective and efficient services delivery in modern library. However, various studies and observation indicates poor state of Internet application in special libraries. Emorjorho and Nwalo (2009) found in their study that only very few libraries in the Niger - Delta of Nigeria uses ICT in library operations where University Libraries have more ICT facilities than the special libraries.

Based on the preliminary investigation, the following issues have been identified. The situation of Internet availability and application in special Libraries in Kaduna State is no exception. The application of Internet to special library services in Kaduna seems inadequate due to some reasons which include fear, and the state of infrastructural development of the state. Most of the library practitioners prefer the manual library operations and services. Those who are aware of its benefits are afraid of being eliminated from their jobs; though knowing that its application to library services such as acquisition, cataloguing and classification, circulation, reference, selective dissemination of information, interlibrary loan and bibliographic services would help for effective and efficient service delivery. In view of these, it is imperative to carry out this investigation. The study is to find out the Internet services that are applied to special library services in Kaduna metropolis to ensure effective service delivery as well as assess its impacts on the library 
services, and the problems encountered in its application by librarians and information seekers.

\section{Research Questions}

The following research questions are formulated to guide the study.

1. What kind of Internet services are used for service delivery in the special libraries in Kaduna metropolis?

2. What library services is the Internet applied for in special libraries in Kaduna metropolis?

3. What is the extent of application of Internet to library services in special libraries in Kaduna?

4. How satisfied are librarians with the use of Internet for services delivery in special libraries in Kaduna metropolis?

5. What are the factors militating against the effective application of Internet services in library services of special libraries in Kaduna metropolis?

\section{Objective of the Study}

Specifically the objectives of the study are to:

1. To ascertain the type of Internet services that are used for service delivery in special libraries in Kaduna metropolis.

2. To find out the library service that Internet is applied for in special libraries in Kaduna metropolis.

3. To ascertain the extent of the application of Internet to library services in special libraries in Kaduna metropolis

4. To determine the extent of satisfaction with the Internet services used for service delivery in the special libraries in Kaduna metropolis.

5. To ascertain the factors that militates against the effective application of Internet services with respect to library services to patrons.

\section{Review of Related Literature The Concept of Internet}

Internet is an abbreviation for International Network. It is not a single Network but a collection of computers worldwide through a system of connection that use the standard Internet Protocol Suite (TCP/IP) to serve billions of users world wide. Agbaje (2002) described the Internet as a veritable tool for global online services. Its availability has paved the way for some associated services in respect of serials such as browsing, e-mail, online system and information management. Similarly Oketunji (2004) states that Internet gives us access to a vast wealth of knowledge access to tools that facilitate research. The use of the Internet in libraries and information centres makes available to the information user a wide range of learning 
resources available on the net especially the World Wide Web (www) and the electronic mail.

On the other hand, Muzakkari (2002) defined Internet as a vast network that connects many independent networks spanning all over the world. It links computers of different type, size and operating system and also to many people that use the Internet to communicate. The Internet is also referred to as virtual library. It does not only offer access to many libraries, but it gives access to topics of special interest using the web sites.

\section{Internet Services and Resources Use for Services Delivery}

The Internet provides a number of services and resources for the purpose of retrieving and disseminating of information to and from computers on the network. Ajileye (1996) opined that, the Internet offers a wide range of services. These include: electronic mail, bulletin board, file transfer, remote login, index programme, news group, electronic surfing, and video conferencing all these services are used in libraries, education, commerce, economy, and production among others. Also Laura (2001) describes the components of the Internet to be of different stages, which are interrelated and are backbone to its application and argue that the Internet resources are about seven; gopher, e-mail, telnet, chat and instant messaging, discussion group, file transfer protocol, and world wide web. Muzakkari (2002) stated that Internet resources are the resources available in the net. These electronic resources include: e-mail, chat groups, file Transfer Protocol, and so on. Each of these resources has its own set of rules, but they relate to one another in several ways (Monereo, et al, 2000). The Internet offers several search tools/applications that can assist a user to look for particular document or information on a given topic (Monereo, et al; 2000). The search tools/applications include: Search engines, Meta Search engines, subject directories, etc. These search engines includes: Google(http://www.google.com), Alta Vista (http://www.altavista.com), Lycos (http:www.lycos.com), Excite (http://www.excite.com)Ask Jeeves (http://www.ask.com).

\section{Application of Internet in Library Services}

The Internet has integrated nearly all aspects of the library activities. It plays an important role in service delivery in libraries. Internet is changing the ways the libraries organize, manage, and disseminate information. Different types of library services from membership registration, acquisition, cataloging, resource sharing, circulation, Inter Library Loan, reference services, current awareness service, selective dissemination of information, and document delivery can be offered through the Internet. The advanced use of Internet tools enable libraries to reach both local and distance users much 
more easily and effectively. Internet tools such as email and web provides tremendous opportunities for library and information professionals to deliver the information to their users. The activities that were carried out manually in libraries with so much stress and strains are now being carried out smoothly with the help of ICT with greater effectiveness.

Internet is applied to the services of special libraries to ensure that information is delivered timely, accurately and precisely. Libraries are using the Internet to support their fundamental functions and services. Butt, Qutab and Mahmood, (2011) reported in their study on Internet use in library functions and services in libraries of Lahore that Internet is applied mostly in acquisition, classification and cataloguing, reference, document delivery, current awareness service, selective dissemination of information and Interlibrary loan to enhance service delivery and at the same time save time. The study conducted by Okafor (2011) revealed that the librarians and academics in the Institutions studied utilize the Internet very much in carrying out its services and research with University of Ibadan $69.4 \%$, University of Benin 60.4\%, University of Agriculture, Abeokuta 57.1\%, University of Nsukka 53.6\%, this help in meeting the information needs of the users.

Internet offers to the special library patrons the ability of browsing and therefore selecting library materials of other famous libraries of the world such as library of congress, USA, Alexandra Library, Nigerian National Library etc. With the application of Internet in libraries, librarians can perform their functions more effectively and efficiently while patrons will get satisfactory answer to their query/queries within the shortest time, as Faboyinde (2006) opined that the application of Internet in Nigerian libraries shows consciousness of the significant role Internet play in delivering library services.

\section{Satisfaction Derived in the Application of Internet Services to Library Services}

The impacts of new technologies are felt by libraries in every aspect. Internet is being increasingly used in library and information services for the acquisition, Processing and dissemination of information. Internet plays a major role in making communication online possible and very easy. According to Singh (2002) Internet has helped to transform the library system and the way in which we view the library resources and library services. With the help of web based library services in developed countries, users are attended round the clock. Internet provides links to various library sites, specializing in almost every topic and they can be accessed directly from any part of the world. 
Internet plays an important role in enhancing efficiency in development of library services. Internet is changing the network of libraries and information centres. Its application in library services is believed to have had tremendous effect in libraries. Most services that were very difficult or even impossible to be performed are now carried out without any form of difficulty. Osuala (2007) stated that client can get satisfactory answers to their query/queries within the shortest time while libraries can perform their functions more effectively and efficiently with the help of the Internet. Internet has become a basic ingredient of information accessibility and dissemination. Many libraries have their catalogue of books and non-books in the web and accessibility to those catalogues is made easier and possible through Internet

Furthermore, Okore (2005) reported that in Nigeria significant development and achievement on the use of automated systems have been recorded in academic and research libraries. There are now thousands of Internet 'home pages' which serve as information sources for institutions and organizations. Most universities and research institutes throughout the world have established their presence on the Internet, thereby making it possible for researchers to access past and current research publication.

\section{Problems of use of Internet Services in Nigeria}

The introduction of Internet technology is a welcome development to the information professionals, thus, their use by the library poses some challenges. In developing societies like Nigeria, the application of technologies in different sectors such as libraries and information centres, health, banks, industrial sector etc, have been affected by some problems. Okore (2005) emphasized the problems that are associated with the use of information and technologies in developing countries with reference to Nigeria as, poor economic state of the nation, lack of ICT infrastructure, access and connectivity in many parts of the country, erratic power supply and government attitude towards technological development. Ojedokun (2007) identified inadequate funding, epileptic power supply, limited computer/ information technology literacy, ineffective planning and poverty and lack of skilled manpower and inadequate skilled manpower as challenges to effective ICT application in Nigeria.

One of the constraints to effective application of Internet in Nigeria libraries is low level of computer culture. When librarians are not computer literate, utilizing the facility would be a problem. This asserts the point Urbana Champain (2005) that lack of government funding, limited and expensive Internet bandwidth, unstable power sources, and insufficient staff development as factors that affect job performance of librarians. Afolabi and Abidoye (2013) stated that poor infrastructural facilities, low level of ICT 
compliance, poor maintenance of ICT equipment, lack of ICT policies, inadequate technical and skilled manpower, erratic power supply, poor funding, and technology obsolescence are barriers to effective ICT integration in library services.

Islam and Panda (2009) studied Internet connectivity in the special Libraries of Bangladesh and found it far from satisfactory. The survey revealed that only $28 \%$ special libraries had Internet connectivity. Also Semertzaki (2008) in his study noticed obstacles in accessing the Internet due to slow access speed and low computer capacity in some of Greek Libraries. One of the most disruptive problems to Internet application is the erratic nature of electricity in Nigeria. Electricity problem has over the years adversely affected the installation and running of computer networks. In order to keep the services running people and organizations lay huge investment acquiring generators for the supply of electricity which in some countries are taken for granted.

\section{RESEARCH METHODOLOGY}

Survey method of research was adopted for this study. Survey method is defined as a systematic way of collecting data concerning an event, activities and users at the same given time and it enables the researcher to reach out to the study population in their different locations. The population of the study was limited to the library staff of the special libraries in Kaduna metropolis. Although four special libraries were involved in this study, the choice of this population group was based on the fact that they have Internet facilities which are accessible. Thus, all the library staff of the selected special libraries formed the population of the study. Based on the information from the head of libraries and deputy librarians of the special libraries, there are 20 library staff in Nigerian Institute for Trypanosomiasis Research, Sunami Road; National Water Resources Institute, Mando, 11 library staff; Court of Appeal,Kawo,7 library staff; Federal High Court, 5 library staff.

Table 1: showing the sample size and percentage of the population

\begin{tabular}{|l|l|l|}
\hline Institutions & Library staff & Percentage (\%) \\
\hline NITR & 20 & 46.5 \\
\hline NWRI & 11 & 25.6 \\
\hline Court of Appeal & 7 & 16.3 \\
\hline Federal High Court & 5 & 11.6 \\
\hline Total & 43 & 100 \\
\hline
\end{tabular}

The entire population i.e., special libraries in Kaduna Metropolis could not be studied for the research. Thus, purposive sampling method was used for the study to select four (4) special libraries because of their relevance to the investigation. This was because these special libraries have Internet 
facilities which are accessible. Therefore the overall total of forty three (43) respondents was sampled for this study.

In order to produce a reliable and dependable result in this study, two major instruments were used for data collection. These were questionnaire and personal observation.

Observation helps to ascertain the authenticity of the availability of Internet resources and personnel in the libraries. The data collected through the questionnaire for this research work and observation were organized and analyzed using descriptive statistics so as to obtain answers to the research questions formulated. Frequency distribution tables and simple percentages were used to analyze the data.

\section{DATA PRESENTATON AND ANALYSIS}

This chapter presented, analyzed, and discussed the data that were collected for the study. The presentation and the analysis of data were done under the following sub-headings: Response Rate, The available Internet services use in the special libraries, Application of Internet services to special library services, Extent of the application of Internet in library services delivery, Levels of satisfaction in the application of Internet to library services delivery, Factors affecting the application of Internet services for effective service delivery in the special libraries. The findings were based on responses collected.

\section{Response Rate}

The field work was restricted to selected special libraries with Internet services in Kaduna Metropolis. However, four special libraries were used for the study. Fifty three (43) Library staffs were served with the copies of the questionnaire as respondents and fifty one (38) were completed and returned, this constituting $88.3 \%$.

Table 2: Response Rate

\begin{tabular}{|l|l|l|l|}
\hline Libraries & $\begin{array}{l}\text { Questionnaire } \\
\text { Distribution }\end{array}$ & $\begin{array}{l}\text { Questionnaire } \\
\text { Retrieved }\end{array}$ & $\begin{array}{l}\text { Percentage } \\
(\%)\end{array}$ \\
\hline $\begin{array}{l}\text { Nigerian Institute for Trypanosomiasis } \\
\text { Research (NITR) }\end{array}$ & 20 & 16 & 37.2 \\
\hline $\begin{array}{l}\text { National Water Resources Institutes } \\
\text { (NWRI) }\end{array}$ & 11 & 11 & 25.6 \\
\hline Court of Appeal & 7 & 6 & 13.9 \\
\hline Federal High Court & 5 & 5 & 11.6 \\
\hline Total & 43 & 38 & 88.3 \\
\hline
\end{tabular}

Details of table 2 revealed that six special libraries in Kaduna metropolis were sampled. Their representation showed that NITR had 16 respondents (37.2\%), NWRI had 11 respondents (25.6\%), Court of Appeal 
had 6 respondents (13.9\%), and Federal high Court had 5 respondents (11.6\%).

Research Question One: Kinds of Internet Services used in Special Libraries in Kaduna Metropolis

Table- 3: Kinds of Internet Services used in Special Libraries in Kaduna Metropolis

\begin{tabular}{|l|l|l|l|l|l|l|l|}
\hline \multirow{2}{*}{$\begin{array}{l}\text { S/ } \\
\text { No }\end{array}$} & Internet Services & \multicolumn{4}{|c|}{ Library } & \multicolumn{2}{|c|}{ Total } \\
\cline { 3 - 8 } & & NITR & NWRI & $\begin{array}{l}\text { Court of } \\
\text { Appeal }\end{array}$ & $\begin{array}{l}\text { Federal } \\
\text { High } \\
\text { Court }\end{array}$ & Freq & $\%$ \\
\hline 1 & $\begin{array}{l}\text { Electronic Mail (e- } \\
\text { mail) }\end{array}$ & 10 & 8 & 7 & 5 & 30 & 69.8 \\
\hline 2 & $\begin{array}{l}\text { World Wide Web } \\
\text { (www) }\end{array}$ & 16 & 9 & 7 & 4 & 36 & 83.7 \\
\hline 3 & Internet chat & 5 & 3 & 2 & 1 & 11 & 25.6 \\
\hline 4 & Internet Telephone & - & 1 & 1 & - & 2 & 4.7 \\
\hline 5 & $\begin{array}{l}\text { Electronic Library } \\
\text { (e-library) }\end{array}$ & 6 & 7 & 3 & 2 & 18 & 41.8 \\
\hline 6 & Web 2.0 & - & - & - & - & - & - \\
\hline 7 & $\begin{array}{l}\text { Online } \\
\text { Access(OPAC) }\end{array}$ & 2 & 2 & - & - & 4 & 9.3 \\
\hline 8 & Own Website & 10 & 7 & 7 & 2 & 26 & 60.5 \\
\hline
\end{tabular}

The findings from the table 3indicates that the items librarians mostly used are: Electronic mail (e-mail), World Wide Web (www), Electronic Library and Own Website in the tune of 30(69.8\%), $36(83.7 \%), 18(41.8 \%), 26(60.5 \%)$ respectively. On the other hand, Internet chat,Internet Telephone, and OPAC are not reasonably used in the special libraries studied in the tune of $11(25.6 \%), 2(4.7 \%)$, and 4(9.3\%) respectively, while Web 2.0 are not used at all. However, World Wide Web and e-mail services were found to be considerably used in the libraries studied. This confirms the earlier report of University Libraries (2003) that almost all the information searches on the Internet are handled through world wide web.

Research Question Two: Library Services Internet is applied for in Special Libraries in Kaduna metropolis.

Table- 4: Library Services Internet is applied in Special Libraries in Kaduna Metropolis

\begin{tabular}{|l|l|l|l|l|l|l|}
\hline Library Services & \multicolumn{3}{|c|}{ Library } & \multicolumn{2}{c|}{ Total } \\
\hline & NITR & NWRI & $\begin{array}{l}\text { Court of } \\
\text { Appeal }\end{array}$ & $\begin{array}{l}\text { Federal } \\
\text { High } \\
\text { Court }\end{array}$ & Freq & $\%$ \\
\hline \multicolumn{1}{|c|}{ Acquisition } & 2 & 2 & 1 & - & 5 & 11.6 \\
\hline $\begin{array}{l}\text { Cataloguing/ } \\
\text { Classification }\end{array}$ & 1 & 1 & - & - & 2 & 4.6 \\
\hline Reference services & 2 & 2 & - & - & 4 & 9.3 \\
\hline Current Awareness & 2 & 2 & 1 & - & 5 & 11.6 \\
\hline
\end{tabular}




\begin{tabular}{|l|l|l|l|l|l|l|}
\hline services & & & & & & \\
\hline $\begin{array}{l}\text { Selective } \\
\text { Dissemination of } \\
\text { Information }\end{array}$ & 3 & 2 & 1 & - & 6 & 13.9 \\
\hline Interlibrary loan & 1 & 1 & - & - & 2 & 4.6 \\
\hline Document Delivery & - & - & - & - & - & - \\
\hline Circulation & - & - & - & - & - & - \\
\hline $\begin{array}{l}\text { Bibliographic } \\
\text { service }\end{array}$ & 1 & 1 & - & - & 2 & 4.6 \\
\hline
\end{tabular}

Table 4 shows the response of respondents on the library services where Internet is applied in the libraries studied. These revealed that Internet services are not reasonably applied in all the library services of the selected libraries.

Based on the analysis, it could be seen that Internet services are not applied in most of the library services rendered to the clientele in the special libraries in Kaduna metropolis to a certain degree. This implies that application of Internet services in the services of the libraries studied is not significantly high.

Research Question Three: Extent of the application of Internet in Library Services

Table- 5: Extent of the application of Internet in the libraries studied

\begin{tabular}{|c|c|c|c|c|c|c|c|c|c|c|c|c|}
\hline \multirow[t]{3}{*}{ Libraries } & \multicolumn{10}{|c|}{ Extent of Application } & \multicolumn{2}{|c|}{ Total } \\
\hline & \multicolumn{2}{|c|}{$\begin{array}{l}\text { Very } \\
\text { large } \\
\text { extent }\end{array}$} & \multicolumn{2}{|c|}{$\begin{array}{l}\text { Large } \\
\text { extent }\end{array}$} & \multicolumn{2}{|c|}{ Unsure } & \multicolumn{2}{|c|}{$\begin{array}{l}\text { Small } \\
\text { extent }\end{array}$} & \multicolumn{2}{|c|}{$\begin{array}{l}\text { Very } \\
\text { small } \\
\text { extent }\end{array}$} & & \\
\hline & $\mathbf{F}$ & $\%$ & $\mathbf{F}$ & $\%$ & $\mathbf{F}$ & $\%$ & $\mathbf{F}$ & $\%$ & $\mathbf{F}$ & $\%$ & $\mathbf{F}$ & $\%$ \\
\hline NITR & - & - & 1 & 2.6 & 2 & 5.3 & 11 & 28.9 & 2 & 5.3 & 16 & 42.1 \\
\hline NWRI & - & - & 1 & 2.6 & 1 & 2.6 & 8 & 21.1 & 1 & 2.6 & 11 & 28.9 \\
\hline $\begin{array}{ll}\text { Court } & \text { of } \\
\text { Appeal } & \\
\end{array}$ & - & - & 1 & 2.6 & - & - & 5 & 13.2 & - & - & 6 & 15.8 \\
\hline $\begin{array}{l}\text { Federal } \\
\text { High } \\
\text { Court }\end{array}$ & - & - & - & - & 1 & 2.6 & 2 & 5.3 & 2 & 5.3 & 5 & 13.2 \\
\hline Total & - & - & 3 & 7.9 & 4 & 10.5 & 26 & 68.4 & 5 & 13.2 & 38 & 100 \\
\hline
\end{tabular}

It is evidence from table 5, that Internet is not applied to a very large extent in the library services. The table also shows that $3(7.9 \%)$ of the libraries applied Internet to a large extent. Also 4(10.5\%) of the libraries were unsure of the extent of application of Internet in their library services, while 26(68.4\%) of the libraries applied Internet to a small extent. Moreover, $5(13.2 \%)$ of the libraries applied Internet to a very small extent in their 
library services. This implies that the Internet is not well applied to services of the libraries studied.

Research Question Four: Extent of Satisfaction Derived in the Application of Internet Services for Service Delivery.

Table-6: Extent of Satisfaction in the Application of Internet Services for Service Delivery

\begin{tabular}{|c|c|c|c|c|c|c|c|c|c|c|c|c|}
\hline \multirow[t]{3}{*}{ Libraries } & \multicolumn{10}{|c|}{ Level of Satisfaction } & \multicolumn{2}{|c|}{ Total } \\
\hline & \multicolumn{2}{|c|}{$\begin{array}{l}\text { Very } \\
\text { satisfied }\end{array}$} & \multicolumn{2}{|c|}{ Satisfied } & \multicolumn{2}{|c|}{ Unsure } & \multicolumn{2}{|c|}{ Dissatisfied } & \multicolumn{2}{|c|}{$\begin{array}{l}\text { Very } \\
\text { Dissatisfied }\end{array}$} & & \\
\hline & $\mathbf{F}$ & $\%$ & $\mathbf{F}$ & $\%$ & $\mathbf{F}$ & $\%$ & $\mathbf{F}$ & $\%$ & $\mathbf{F}$ & $\%$ & $\mathbf{F}$ & $\%$ \\
\hline NITR & - & - & 7 & 18.4 & 3 & 7.9 & 5 & 13.2 & 1 & 2.6 & 16 & 42.1 \\
\hline NWRI & - & - & 6 & 15.8 & 1 & 2.6 & 4 & 10.5 & - & - & 11 & 28.9 \\
\hline $\begin{array}{l}\text { Court of } \\
\text { Appeal }\end{array}$ & - & - & 4 & 10.5 & - & - & 2 & 5.3 & - & - & 6 & 15.8 \\
\hline $\begin{array}{l}\text { Federal } \\
\text { High } \\
\text { Court }\end{array}$ & - & - & 2 & 5.3 & - & - & 3 & 7.9 & - & - & 5 & 13.2 \\
\hline Total & - & - & 19 & 50 & 4 & 10.5 & 14 & 36.9 & 1 & 2.6 & 38 & 100 \\
\hline
\end{tabular}

The table 6 shows that none of the respondents were very satisfied with the application of Internet to services delivery in the libraries, while 19(50\%) were satisfied, 4(10.5\%) were unsure, 13(34.2\%) were dissatisfied and $1(2.6 \%)$ was very dissatisfied. The analysis shows that a good number (50\%) of the respondents derived satisfaction with the present application of Internet in services delivery in the libraries studied. This supports Osuala (2000), assertion that clients get satisfactory answers to their query/queries within the shortest time while librarians can perform their functions more effectively and efficiently with the help of the Internet. It also supports Mohammed (2007) findings on the use of ICT based resources and services in special libraries of kerala that a good number (56.4\%) of the library staff and $50 \%$ of users of state Government institution libraries were satisfied with the availability and application of ICTs in their libraries. This implies that effective and efficient service delivery in the libraries is dependent on the availability and effective application of Internet services. 
Research Question 5: Factors Affecting the Application of Internet Services for Service Delivery in the Special Library of Kaduna State.

Table 7: Factors affecting the Application of Internet Services for Services Delivery in the Special Libraries in Kaduna Metropolis

\begin{tabular}{|c|c|c|c|c|c|c|c|c|c|c|c|c|c|}
\hline \multirow[t]{2}{*}{$\begin{array}{l}\text { S/ } \\
\text { No }\end{array}$} & \multirow{2}{*}{$\begin{array}{l}\text { Factors Affecting the } \\
\text { effective } \\
\text { application } \\
\text { Internet services }\end{array}$} & \multicolumn{2}{|c|}{$\begin{array}{l}\text { Strongly } \\
\text { Agree }\end{array}$} & \multicolumn{2}{|c|}{ Agree } & \multicolumn{2}{|c|}{$\begin{array}{l}\text { Undecide } \\
\text { d }\end{array}$} & \multicolumn{2}{|c|}{ Disagree } & \multicolumn{2}{|c|}{$\begin{array}{l}\text { Strongly } \\
\text { Disagree }\end{array}$} & \multicolumn{2}{|c|}{ Total } \\
\hline & & $\begin{array}{l}\text { F } \\
\mathbf{q}\end{array}$ & $\%$ & $\begin{array}{l}\mathbf{F} \\
\mathbf{q}\end{array}$ & $\%$ & $\begin{array}{l}\mathbf{F} \\
\mathbf{q}\end{array}$ & $\%$ & $\mathbf{F q}$ & $\%$ & $\begin{array}{l}\mathbf{F} \\
\mathbf{q}\end{array}$ & $\%$ & $\begin{array}{l}\mathbf{F} \\
\mathbf{q}\end{array}$ & $\%$ \\
\hline 1 & $\begin{array}{l}\text { High cost of } \\
\text { connectivity and } \\
\text { Maintenance }\end{array}$ & 19 & 50 & 13 & 34.2 & 2 & 5.3 & 4 & 10.5 & - & - & 38 & 100 \\
\hline 2 & Low bandwidth & 12 & 31.6 & 11 & 29 & 4 & 10.5 & 7 & 18.4 & 4 & 10.5 & 38 & 100 \\
\hline 3 & Erratic power supply & 19 & 50 & 13 & 34.2 & 1 & 2.6 & 3 & 7.9 & 2 & 5.3 & 38 & 100 \\
\hline 4 & $\begin{array}{l}\text { Poor funding for } \\
\text { Internet Services }\end{array}$ & 10 & 26.3 & 20 & 52.6 & 2 & 5.3 & 5 & 13.2 & 1 & 2.6 & 38 & 100 \\
\hline 5 & $\begin{array}{l}\text { Having problems } \\
\text { with the browser e.g. } \\
\text { poor connection, get } \\
\text { disconnected and } \\
\text { turning out. }\end{array}$ & 9 & 23.6 & 11 & 29 & 3 & 7.9 & 12 & 31.6 & 3 & 7.9 & 38 & 100 \\
\hline 6 & $\begin{array}{l}\text { Low level of } \\
\text { computer literacy } \\
\text { required for effective } \\
\text { use. }\end{array}$ & 2 & 5.3 & 13 & 34.2 & 5 & 13.2 & 12 & 31.6 & 6 & 15.8 & 38 & 100 \\
\hline 7 & $\begin{array}{l}\text { Technology } \\
\text { obsolescence }\end{array}$ & 7 & 18.4 & 18 & 47.4 & 3 & 7.9 & 7 & 18.4 & 3 & 7.9 & 38 & 100 \\
\hline 8 & $\begin{array}{l}\text { Lack of maintenance } \\
\text { culture }\end{array}$ & 11 & 29 & 15 & 39.4 & 2 & 5.3 & 8 & 21 & 2 & 5.3 & 38 & 100 \\
\hline
\end{tabular}

The table 7 shows that a good number of respondents agree that poor funding 20(52.6\%) is the major factors affecting effective application of Internet services, followed by erratic power supply 19(50\%), high cost of connectivity and maintenance 19(50\%), technology obsolescence 18(47.4\%), and low bandwidth 12(3.6\%). It also indicate that 15(39.4\%), 13(34.2\%), and 12(31.6\%) disagree that lack of maintenance culture, lower level of computer literacy required for effective use, having problem with the browser respectively are factors affecting effective application of internet in the libraries under study. This analysis shows that a good number of the respondents agreed that the factors listed are responsible for ineffective application of Internet services in the libraries for quality service delivery. 


\section{Analysis of open-ended questions.}

A total of 32 suggestions were given by the library staff in response to the open-ended question seeking suggestions for improvement on the application of Internet services in the library. For the purpose of data analysis, suggestions were grouped into 3 categories: more funding and maintenance of Internet services, training of staff on ICT and provision of stable power source. Table 4.7 gives the categories of suggestions.

Table 8: Categories of Suggestions for improvement on the application of Internet services in the libraries Studied

\begin{tabular}{|l|l|l|l|}
\hline S/NO. & Category 0f suggestion & Frequency & $\begin{array}{l}\text { Percentage } \\
(\%)\end{array}$ \\
\hline 1 & More funding for maintenance & 7 & 26.9 \\
\hline 2 & Training of staff on ICT development & 9 & 34.6 \\
\hline 3 & Provision of stable power source & 10 & 38.5 \\
\hline & Total & 26 & $100 \%$ \\
\hline
\end{tabular}

Of the 32 suggestions, 7 (26.9\%) respondents suggested more funding for maintenance of the Internet, 14 (34.6\%) suggested training of staff on ICT development, and 10 (38.5\%) suggestions were related to provision of stable power source.

\section{Analysis of the Observation}

It was observed that Internet connectivity is available in the selected special libraries for accessibility by both the library staff and users. However, the researcher on a close observation noticed that most of the Internet services are not used in the special libraries studied.

\section{Discussion of Findings}

1. From the findings, it is obvious that the internet services that are considerably used in the libraries studied are World Wide Web, followed by e mail, own websites and e-library. However, internet chat, internet telephony, and OPAC are not reasonably used, while Web 2.0 is not used at all. This confirms the earlier report of University Libraries (2003) that almost all the information searches on the Internet are handled through www, and also Kennedy (1999) observation that e-mail is the most used application on the Internet for communicating with others. This is because they are readily available for use in the libraries. This result implies that the use of Internet services in the libraries studied was not considerably high, but it is used in such a way that it enhances the quality of service delivery in the libraries. Therefore it could be deduced from the analysis that special Libraries in Kaduna metropolis are still trying to meet up with globalization and information technology. 
2. The findings also revealed that internet are not reasonably applied in all the library services of the special libraries studied. This means that special libraries in Kaduna are making effort at computerization of library resources and services.

3. On the extent of application of Internet in the library services, the study revealed that Internet is not applied to a large extent in the library services of the special libraries studied.

4. Majority of the respondents agreed that the derived satisfaction with the application of internet services in library services because it increases work efficiency.

5. The result of the study also revealed that the majority of the respondents identified poor funding, erratic power supply, high cost of connectivity, technology obsolescence and low bandwidth as the major problems militating against the effective application of Internet services for efficient service delivery in the selected libraries. This is in line with, Oketunji (1999), and Ishola et al (2016)who opine that erratic power supply, problem of technical staff, cost of connection, lack of sustainable wired and wireless network, high cost of ICT, lack of ICT strategy, inadequate ICT facility and exploitative local computer market are challenges of effective Internet connectivity. This implies that the factors listed hinder the effective application of Internet services in service delivery in the special libraries studied. Therefore, for effective application of Internet services for efficient service delivery in these libraries, all these factors must be tackled.

\section{Conclusion}

In line with the findings of this study, the researcher concluded that special libraries in Kaduna state are still on the verge of meeting up with the global perspective of ICT compliance. This notwithstanding, the use of Internet services in the libraries studied was not considerably high, but it is used in such a way that librarians can apply them to library service to enhance the quality of their service delivery. Also, librarians in the libraries studied derived satisfaction in the application of Internet in their libraries. However, several factors such as poor funding, erratic power supply, high cost of connectivity and maintenance, and low bandwidth have been identified as major factors militating against effective application of the Internet services by the librarians.

\section{Recommendations}

Based on the findings and conclusion of this study, this work is recommending the following as a means of facilitating maximum application of Internet services to service delivery. 
- Internet services should be adequately used by the special libraries in Kaduna metropolis in carrying out the housekeeping operations and services of the library, like acquisition, interlibrary loan, document delivery, circulation, serials management, bibliographic services and preservation of material for effective service delivery. This is necessary because Internet services are regarded as integral part of efficient library services.

- Since librarians derive high satisfaction in the application of Internet services in library services, libraries administrations in Kaduna metropolis should make sure that there is steady power supply in the libraries for effective use of the Internet services for service delivery.

- The special libraries should make sure that Internet facilities are serviced regularly; fault should be promptly detected and corrected to enable the Internet to work effectively for efficient service delivery.

- In order for special libraries in Kaduna to provide effective service delivery, they should open an electronic library where the staff and the researchers who do not have good knowledge of ICT can be trained so as to develop the skill to exploit the information available for them in the Internet. A well trained librarian in ICT and Internet application can perform effectively and efficiently in his/her work place than the person who is not trained at all.

\section{References:}

1. Adesanya, O. (2002). The impact of Information technology on Information Dissemination. In: Madu C.E and Dirisu M.B. Information Science \& Technology for library School on Africa. Ibadan: Evi-Coleman Publications. Pp. 21

2. Afolabi, A.F. and Abidoye, J.A. (2013). The integration of information and communication technology in library operations towards effective library services: proceedings of the $1^{\text {st International }}$ Technology, Education, and Environment Conference, African Society for Scientific Research (ASSR) p. 625-626

3. Agbaje, A.A. (2002): "Great Expectations: Serials Management and Information Technology” In: Madu, E.C. and Dirisu, M.B. (eds.). Information Science and Technology for Library School in Africa. Ibadan: Evi-Coleman Publications; Pp. 25 - 36.

4. Ajileye, E.O. (1996) Internet Technology in the Academics: Implications for Librarians in Nigeria. NBTE workshop report on effective management of polytechnic Libraries:- Edited by E.A Olalere, Kaduna: NBTE. 
5. Butt, K; Qutab S; and Mahmood, Khalib (2011). Access and use of the Internet in the Libraries of Lahore, Pakistan. Chinese Librarianship: An International Electronic Journal, 31. $\quad$ Retrieved September 15, 2012 from http://www.iclc.us/cliej/pdf

6. Dirisu, M. B. (2002). "Special Libraries and Information Technology” In: Madu, E.C. and Dirisu, M.B. (eds.). Information Science and Technology for Library School in Africa. Ibadan: Evi-Coleman Publications; Pp. 78 - 82.

7. Emojorho, D. (2011), ICT and Collection Management in Public Libraries: A Survey of South- South of Nigeria. Library Philosophy and Practice. ISSN 1522-0222 Available at http:/digitalcommons.unl.edulibphilprac. Accessed on $23^{\text {rd }}$ November, 2016

8. Faboyinde, E.O. (2006). The state of Information and Communication Technology (ICT) in selected libraries in Lagos and Ibadan Metropolis. Paper presented at the $44^{\text {th }}$ Annual conference and General Meeting of the Nigerian Library Association, Abuja, p.61-68

9. Gbaje, E. Shiloba (2007). Provision of online Information services in Nigeria Academic Libraries: Journal of Nigeria Library Association, Vol. 40

10. Imeremba, D. U. (2004). Development of Library and Information Science: A cursory Appraisal of Nigeria in World Prospective. Abakaliki: Willy Rose \& Appleseed Publishing

11. Ishola et al (2016), Availability, accessibility and use of e-resources in selected private universities in South West, Nigeria. Middlebelt Journal of Library and Information Science, 14 (1) 160

12. Islam, A and Panda, K.C. (2009). Information Technology in special Libraries in Bangladesh: a case study. The Electronic Library, 27 (1), 142-161

13. Kennedy. A. J. (1999). The Internet. London: Rough Guide Ltd.

14. Mohammed, H.K, (2007). Use of ICT based resources and services in special libraries in Kerala: Annals of library and Information studies, Vol. 54 PP. 23-30

15. Monereo. C. Fuentes, M; \& Sanchez, S (2000) Internet search strategies used by experts and beginners Interactive Educational Multimedia, 1, 24-34 (Electronic version). Retrieved September15, 2012 fromhttp://www.ub.es/multimedia/iem/down/cl/Internetsearch and Navigation.pdf

16. Muzakkari B.A (2002) Know the Internet. Lagos: SmarkPp 1-10

17. Ojedokun A.A (2007). Transition to Automated library information systems and challenges for libraries in Africa. Information and 
knowledge management indigital age: concept, technologies and African Perspective, Ania, L.O, Mutula S.M, Tiamiyu, M.A (eds) Ibadan: Third world information, P 122- 123

18. Okafor, Victoria N. (2011) Access to Research Information in Cybercafes. The challenges to Academic Libraries. Library Philosophy and Practice 2011. http://www.webpages.uidaho.edu/mbolin/okafor2.htm

19. Oketunji, I. (1999), “Application of Information Technologies in Nigerian Libraries: Problems and Prospects”. Paper presented at the $10^{\text {th }}$ Biennial Conference of the National Association of Library and Information Science Education (NALISE), University of Ibadan, $4^{\text {th }}-7^{\text {th }}$ August.

20. Oketunji, I. (2001). Agenda for putting Information Technology to work in Nigerian Librarians in the New Millenium. In Library and Information Agenda for the New Millenium: A Compendium of Paper presentations at the 2000 NLA Annual Conference and AGM.

21. Oketunji, I. (2004). Library development and the role of Information and Communication Technologies, being a paper presented at National Workshop on Strategies for Managing Technology Services in Libraries and Information Centres, NLA Cataloguing, Classification and Indexing Section, held at Stella Obasanjo Complex, Lokoja, $7^{\text {th }}-24^{\text {th }}$, October

22. Okore, A. M. (2005) The challenges of information Communication Technologies (ICTs) for Nigerian Academic Librairies. Global Review of Library and Information science. 1(1) 84-93.

23. Osuala, E.C. (2007) Introduction to Research Methodology. Onitsha: African Publishers.

24. Semertzaki, E. (2008). Internet Usage in Greek Libraries. The Electronic Library, 26(5), 735-756

25. Singh, Neena (2001) Internet: Importance and usage for Library and Information Professionals. DESIDOC BUTTETIN of Information Technology, 21 (3) 18-2 